\title{
NOTE
}

\section{Population assessment of the endemic angelfish Holacanthus limbaughi from Île de La Passion- Clipperton Atoll (Tropical Eastern Pacific)}

\author{
Eric Clua $^{1,2, *}$, Sandra Bessudo ${ }^{3}$, Jennifer E. Caselle ${ }^{4}$, Claude Chauvet ${ }^{5}$, \\ Christian Jost $^{1,6}$, Alan M. Friedlander ${ }^{7,8}$ \\ ${ }^{1}$ PSL Research University, CRIOBE, USR3278 EPHE-CNRS-UPVD, 58 Avenue Paul ALDUY, 66860 Perpignan, France \\ ${ }^{2}$ Laboratoire d'excellence CORAIL, BP1013, 98729 Papetoai, French Polynesia \\ ${ }^{3}$ Fundacion Malpelo y Otros Ecosystemas Marinos, Carrera 11 No. 87-51 local 4 piso 2, Bogotá, Colombia \\ ${ }^{4}$ Marine Science Institute, University of California Santa Barbara, Santa Barbara, CA 93106, USA \\ ${ }^{5}$ ACREM, 92 Rue Charleroi, 98000 Noumea, New Caledonia \\ ${ }^{6}$ Université de la Polynésie française, BP 6570, 98702 Faa'a, French Polynesia \\ ${ }^{7}$ Pristine Seas, National Geographic Society, Washington, DC 20036, USA \\ ${ }^{8}$ Fisheries Ecology Research Lab, University of Hawai'i, Honolulu, HI 96822, USA
}

\begin{abstract}
We provide the first assessment for a coral reef fish population of a potentially threatened endemic species from a remote and isolated oceanic island. Based on a 3-dimensional (3D) numerical field model of the reef habitat and underwater visual censuses conducted by 2 different teams in February and May 2016, we show that the $3.7 \mathrm{~km}^{2}$ of the Clipperton Atoll reefs shallower than $30 \mathrm{~m}$ host $>50000$ ind. (average density of 0.02 ind. $\mathrm{m}^{-2}$ ) of the endemic Clipperton angelfish Holacanthus limbaughi. Based on limited submersible observations to $150 \mathrm{~m}$, the population likely extends below the $30 \mathrm{~m}$ depth stratum, resulting in an even larger population size and providing a potential depth refuge against expected warming ocean temperatures.
\end{abstract}

KEY WORDS: Coral reef fish · Pomacanthids · Endemicity $\cdot$ Underwater visual census · Video · Marine habitat mapping

\section{INTRODUCTION}

The list of fishes from Île de La Passion-Clipperton Island in the Tropical Eastern Pacific (TEP; Robertson \& Allen 2002) was recently expanded to include 197 fish species from 62 families, with 106 classified as reef fishes (Fourrière et al. 2014). The recent documentation of giant trevally Caranx ignobilis at Clipperton shows that the colonization process is ongoing (Clua et al. 2016). This fish fauna consists of a mix of species from different biogeographic origins, including taxa from the Panamic Province, some of circumtropical distribution, and a high percentage of trans-

\footnotetext{
*Corresponding author: eric.clua@univ-perp.fr
}

Pacific species (Robertson et al. 2004). Despite its remoteness and isolation, Clipperton Atoll has only 7 endemic fishes (3.6\% of the total fish fauna and $6.6 \%$ of the reef fish fauna) (Fourrière et al. 2014). One of the most striking and highly prized of these endemic fishes is the Clipperton angelfish Holacanthus limbaughi (Pomacantidae), which was described by Baldwin in 1963, and named in memory of the ichthyologist Conrad Limbaugh who conducted the Scripps Institution of Oceanography mission to the atoll in the late 1950s (Limbaugh 1959).

Adults of the Clipperton angelfish are mostly bluish grey with a dark head, a large white tail, and

() The authors 2019. Open Access under Creative Commons by Attribution Licence. Use, distribution and reproduction are unrestricted. Authors and original publication must be credited. 
white ventral fins with blue margins. The dorsal and anal fins are angled and have brilliant blue margins, with a distinctive white spot on the upper side of the body just below the lateral line (Fig. 1). Juveniles have narrow blue vertical lines on the head and body. Adults have been reported to be solitary, although they are often observed in pairs or small groups, while juveniles are mainly solitary (Debelius et al. 2003). Maximum total length can reach $30 \mathrm{~cm}$ (Robertson \& Allen 2015). This omnivorous species is restricted exclusively to Clipperton, which has a total areal extent of $<10 \mathrm{~km}^{2}$, including $\sim 4 \mathrm{~km}^{2}$ of reef habitat (Craig et al. 2010).

The threat of increasing frequency and duration of El Niño-Southern Oscillation (ENSO) events in the region (Amador et al. 2016) could cause severe and rapid declines for restricted-range, shallow-water species. However, because it is also found in deeper water (Baldwin 1963), and therefore not expected to be impacted as strongly as more shallow-water species, at least in the near-term, H. limbaughi is currently listed as 'Near Threatened' by the International Union for Conservation of Nature (IUCN) (Craig et al. 2010).

Because of their colorful patterns and unusual body shapes, angelfishes (Pomacanthidae) are one of the most prized fish families in the aquarium trade (Wabnitz et al. 2003). In addition to natural mortality, the Clipperton angelfish is subject to illegal fishing pressure (given that the French government does not grant fishing licences), as a single live individual of this species can be illegally sold for several thousand dollars in US markets and up to USD \$10 000 in Asian markets (ECS 2011). In 2011, an experienced American aquarium fish collector was sentenced to $45 \mathrm{~d}$ in prison and fined USD \$2000 after trying to import 52 specimens into the USA in 2009 under the name of 'blue passer' angelfish Holacanthus passer (ECS 2012).

In this paper, we conduct the most comprehensive assessment to date of the density and population size of the Clipperton angelfish and discuss the potential resilience of this species compared to another pomacanthid from this region.

\section{MATERIALS AND METHODS}

This study was conducted at Clipperton Atoll, located $1080 \mathrm{~km}$ off the west coast of México, at $10^{\circ} 18^{\prime} \mathrm{N}, 109^{\circ} 13^{\prime} \mathrm{W}$ (Fig. 2A). This is the only atoll in the TEP and its $\sim 4 \mathrm{~km}^{2}$ coral reef is the largest in the region (Glynn et al. 1996). The atoll has a closed lagoon with no connection to the open ocean, and is surrounded by well-cemented coral reefs that extend to depths $>40 \mathrm{~m}$. The $50 \mathrm{~m}$ isobath is, on average, $\sim 500 \mathrm{~m}$ from the reef front (Glynn et al. 1996). Between 3 and $30 \mathrm{~m}$ depth, the reef structure is composed predominantly of corals of the genera Porites, Pavona, and Pocillopora. While coral diversity is low in the context of the Indo-Pacific region, coral cover is high with up to $90 \%$ of live coral cover in some areas, mainly between 12 and $18 \mathrm{~m}$ depth (Clua 2016, Jost et al. 2016). These 2 recent surveys estimated average live coral cover of $\sim 60 \%$ around the atoll, which is among the highest in the TEP (Alvarado et al. 2016).

The densities and sizes of Clipperton angelfish were assessed during 2 different field missions in February and in May 2016. In February, 2 divers performed underwater visual censuses (UVCs) and video transects along $50 \times 5 \mathrm{~m}$ strip transects. In total, 27 transects were surveyed at 6 sites around the atoll in shallow (between 10 and $20 \mathrm{~m}$ ) and deep

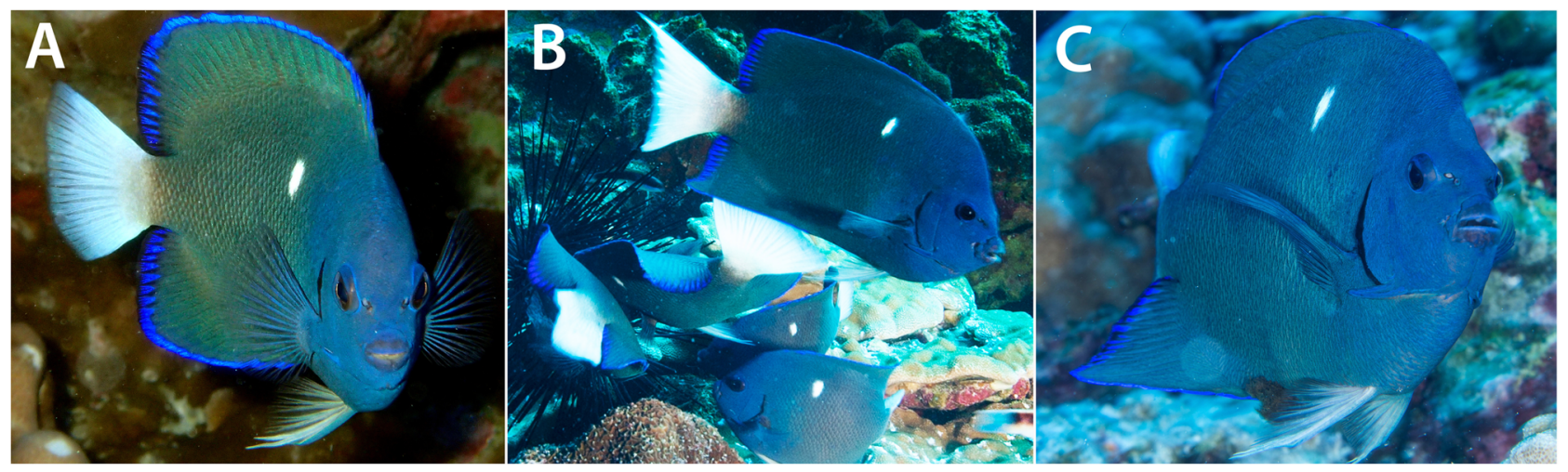

Fig. 1. (A) Sub-adult individual of Clipperton angelfish Holacanthus limbaughi with (B) a feeding aggregation on an urchin and $(\mathrm{C})$ a close-up of an adult 

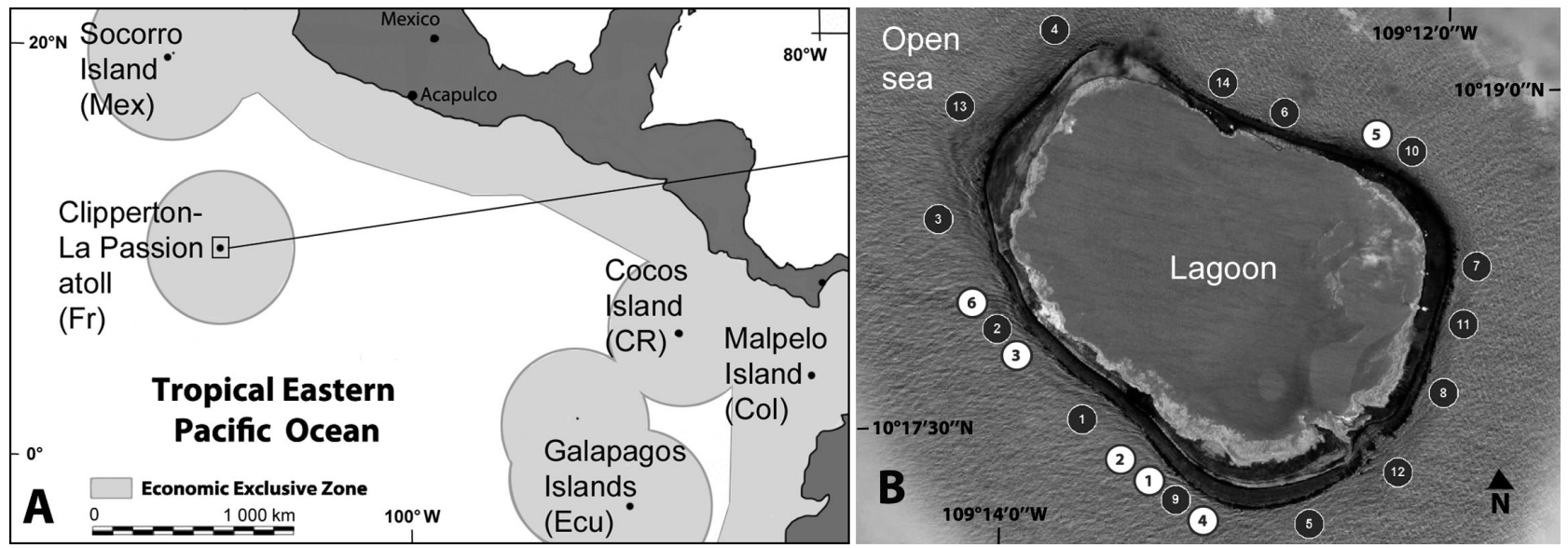

Fig. 2. (A) Île de La Passion-Clipperton Atoll off the Mexican coast, with the closest (945 km) emergent land being the Revillagigedo Archipelago (Mexico) to the north (Socorro Island). (B) February (white circles) and March (grey circles) sampling locations for Holacanthus limbaughi around the atoll. Figures inside the circles refer to the station number (see Table S1 for details)

(between 20 and $30 \mathrm{~m}$ ) waters (Fig. 2B). Both during UVCs and by means of a post-diving analysis of the video footage, fishes were visually tallied and directly classified into 4 different size classes: $\leq 10$, $11-15,16-20$ and $>20 \mathrm{~cm}$. During the second mission in May 2016, at each of 2 depth strata (10 and $20 \mathrm{~m}$ ) within a site, divers counted and estimated lengths for all fishes encountered within fixedlength $(25 \mathrm{~m})$ belt transects whose widths differed depending on the direction of swim. All fishes $\geq 20 \mathrm{~cm}$ total length (TL) were tallied within a $4 \mathrm{~m}$ wide strip as the transect line was laid out $\left(100 \mathrm{~m}^{2}\right)$. All fishes $<20 \mathrm{~cm}$ TL were tallied within a $2 \mathrm{~m}$ wide strip surveyed on the return swim $\left(50 \mathrm{~m}^{2}\right)$. The observers conducted a total of 84 transects at 14 sites $\times 2$ depth strata (Fig. 2B). Fish length was esti- mated to the nearest cm TL. For comparative purposes, all fishes were binned into size classes as described for the February surveys above. Numerical density (abundance) was expressed as number of ind. $\mathrm{m}^{-2}$ (see the Supplement at www.int-res. com/articles/suppl/n038p171_supp.pdf for details of the methodology).

We calculated the area of fish habitat for Holacanthus limbaughi using field data collected in 2015 to develop a 3-dimensional (3D) field numerical model (FNM) of the atoll (Fig. 3A,B), as well as bathymetric data compiled by the Service d'Hydrographie Officiel de la Marine (SHOM) in 2012. From these complementary data, we examined a depth range (at low tide) between 5 and $30 \mathrm{~m}$. This range was chosen since UVC data showed that this species is not fre-

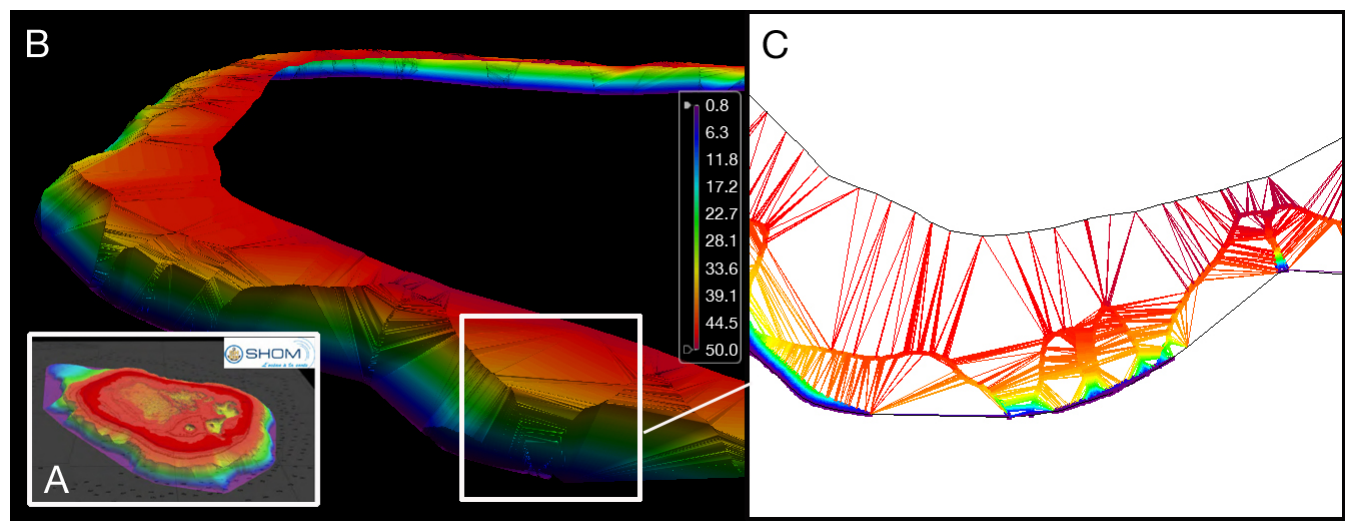

Fig. 3. (A) A 3-dimensional field numerical model of Île de La Passion-Clipperton Atoll, including the lagoon and outer reef slope. The colour bar indicates the inverted depth $(0-50 \mathrm{~m})$. (B) Detail of the bathymetric layers of the outer slope of the western part of the atoll. (C) Detail of the technique of direct links between isobath points that provides the interpolation among the empty spaces and a calculation of the whole surface of a given area of the reef slope 
quently found shallower than $5 \mathrm{~m}$ and no SCUBA diving assessment was performed below $30 \mathrm{~m}$. Data were screened and extrapolated with the software Bathy DataBASE (Teledyne CARIS) through direct links between isobath points and interpolation among the empty spaces (Fig. 3C). This interpolation was then extracted based on a $1 \mathrm{~m}$ grid, and the surface was assessed by counting the number of isobath points around the atoll per $5 \mathrm{~m}$ intervals of bathymetry. The result of this assessment was then compared with and validated against the surface calculated by running the software HYPACK (Xylem) on the 3D FNM.

\section{RESULTS AND DISCUSSION}

Our visual censuses showed Holacanthus limbaughi to be a gregarious species, irrespective of ontogenic stage, contradicting previous information (Debelius et al. 2003). The average $( \pm$ SD) densities for $H$. limbaughi assessed in February 2016 and May 2016 were $0.016 \pm 0.01$ and $0.024 \pm 0.02$ ind. $\mathrm{m}^{-2}$, respectively. For both assessments, the high SDs show high heterogeneity in the spatial distribution of the fishes (see Table S1 in the Supplement for details). The extrapolated fish habitat surface area was $3.7 \pm 0.2 \mathrm{~km}^{2}$, while FNM gave a surface area of $4.0 \pm$ $0.3 \mathrm{~km}^{2}$. Comparisons of fish size structure between assessments in February and May showed that the size frequency data obtained in the 2 sampling dates differed in that the proportion of $<10 \mathrm{~cm}$ fish was smaller, while that of the 16 to $20 \mathrm{~cm}$ size class was larger in May than in February (Fig. 4).

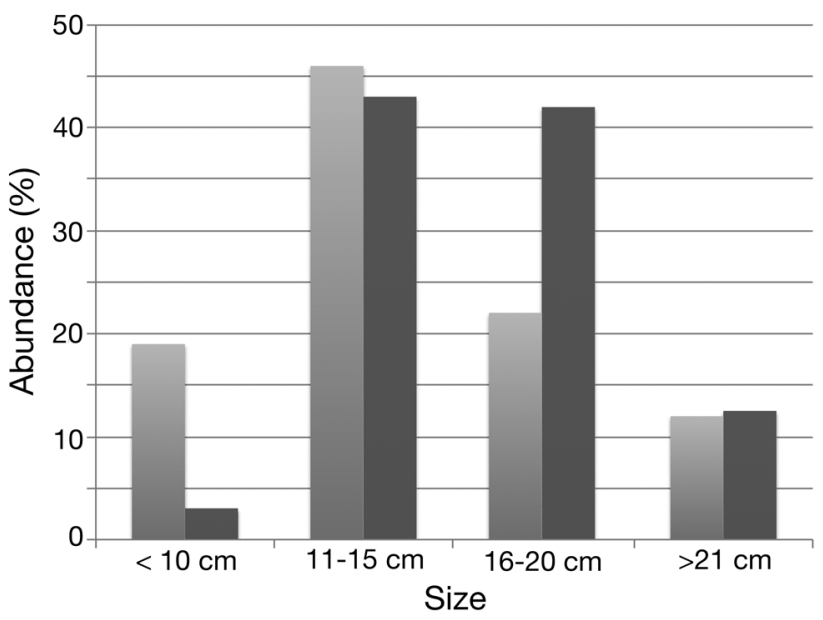

Fig. 4. Distribution of Holacanthus limbaughi size classes in February (light grey) and May (dark grey) based on underwater visual censuses
These 2 independent assessments vary somewhat but are within the same order of magnitude. Both methods of UVC are standard, and while sampling in February 2016 was mainly in the southwest part of the atoll, sampling in May 2016 was performed around the entire atoll. In addition to slightly different densities between sampling periods, the surveys conducted in the southwest area showed a higher number of juvenile $H$. limbaughi ( $<10 \mathrm{~cm}$ TL) compared with the assessment around the entire atoll (19 vs. 3\%, respectively). This difference could result from differences in sampling effort and methods used between the 2 sampling dates, but could also identify the southwestern area as a preferred nursery habitat, as it is more sheltered from the predominant northeast swell. Additional sampling of $H$. limbaughi around the entire atoll would be required to better assess the densities and spatial size structure of the population.

Our most conservative assessment of $3.7 \mathrm{~km}^{2}$ of potential fish habitat between 5 and $30 \mathrm{~m}$ is very similar to the estimate of $4 \mathrm{~km}^{2}$ provided by Craig et al. (2010). Our estimates were based solely on a depth range that was limited by our diving capacities and did not take into account any variation in benthic habitat. In addition, our assumption that Clipperton angelfish are homogenously distributed among all habitats is uncertain. Therefore, a detailed habitat assessment including substrate, complexity and rugosity should be conducted around the island aiming to better define the fish-habitat relationships for this species (Friedlander 2001).

Combining the average fish density from the 2 surveys (approx. 0.02 ind $\mathrm{m}^{-2}$ ) and the area of habitat between 5 and $30 \mathrm{~m}$ depth $\left(3.7 \mathrm{~km}^{2}\right)$ yields a population estimate of 52000 Clipperton angelfish around the atoll. This estimate is slightly higher than a recent population estimate for this species at Clipperton Atoll (Crane et al. 2018). Using visual survey data from the 2016 surveys as well as older surveys, Crane et al. (2018) estimated a total population size from 0 to $50 \mathrm{~m}$ depth of 35600 ind. The lower estimate in that study is likely due to the inclusion of older survey data that had lower densities than the recent surveys, as well as differences in how total area was estimated. Given the methodological differences, the estimates are remarkably similar. A similar density of 0.02 ind. $\mathrm{m}^{-2}$ was found for the Clarion angelfish Holacanthus clarionensis at Cabo Pulmo in the Gulf of California (Mexico) (Alvarez-Filip et al. 2006). Reyes-Bonilla (2016) estimated a total population size of approximately 60700 Clarion angelfish, of which around 10700 were found off the coasts of Baja California Sur. They estimated the potential range of the 
species to be approximately $13365 \mathrm{~km}^{2}$, with an average density of around 0.00454 ind. $\mathrm{m}^{-2}$. The estimates by Reyes-Bonilla (2016) are consistent with Chávez Comparán et al. (2010), who estimated the average density for $H$. clarionensis in Baja California Sur to be $<0.0001$ ind. $\mathrm{m}^{-2}$, and 0.0049 ind. $\mathrm{m}^{-2}$ in the remote Revillagigedo Archipelago, which is $400 \mathrm{~km}$ from the tip of Baja. Although the capacity to sustain small and very isolated populations has been shown to be unrelated to variation in the pelagic larval phase (Robertson 2001), future research into how this ontogenic phase could explain the relative success of $H$. limbaughi is important in understanding population persistence in isolated locations. Understanding the relationship between live coral cover and Clipperton angelfish would also provide a glimpse into future population stability or resilience in the face of climate change and other environmental variation.

Almenara-Rodan \& Ketchum (1994) noted that the populations of $H$. clarionensis suffered a $95 \%$ decline at the Revillegagido Islands at the end of the 1990s because of sport fishing boats that illegally took $>1000$ specimens each trip for the aquarium trade. Models showed an estimated decline in population longevity from 10 to $4 \mathrm{yr}$, with a resultant drop in population size and size of individuals (Reyes-Bonilla 2016). This example of a large depletion in the population of $\mathrm{H}$. clarionensis should be a cautionary tale with respect to fishing for the Clipperton angelfish.

The population assessment of 52000 ind. of H. limbaughi that we present here is conservative and based on a restricted habitat ( $<30 \mathrm{~m}$ of depth); $100 \mathrm{~s}$ (or even 1000s) of individuals of this species may be present in deeper waters, as observed by submarine investigations down to $110 \mathrm{~m}$ depth (Jost et al. 2016, Crane et al. 2018). This discovery supports the hypothesis that $H$. limbaughi might be much more numerous than shown through our assessments, and that this species may be less vulnerable to climate change than other species of the family, which are often restricted to shallow water and coral reefs (Hawkins et al. 2000). Therefore, $H$. limbaughi may be less at risk than $H$. clarionensis due to the isolation of the atoll, a relatively large population size and the fact that it is not coral-dependent (Robertson 1996) and is therefore less vulnerable to ENSO events, which can lead to extensive coral bleaching (Pyle et al. 2010). Therefore, although the endemic $H$. limbaughi is restricted to a limited area, its high density above $30 \mathrm{~m}$ and its capacity to colonize deep habitats even below $100 \mathrm{~m}$ suggest that this species has the potential to be resilient within the context of climate change.
Acknowledgements. This study was conducted in the framework of a mission funded by the USR3278 CRIOBE and authorized by permit no. HC/1838/CAB/BSIRI/MG issued by the High Commissioner of the French Republic in French Polynesia. The authors thank the owners and the organizers of the trip on the 'Quino El Guardian' boat for allowing them to benefit from all the logistics, as well as the technical support from the Mexican crew. We also thank the technical support given by the National Geographic's Pristine Seas Project.

\section{LITERATURE CITED}

Almenara-Rodan S, Ketchum JT (1994) Forgotten islands of the Mexican Pacific. OFI J 9:12-14

* Alvarado JJ, Cortés J, Guzman H, Reyes Bonilla H (2016) Bioerosion by the sea urchin Diadema mexicanum along Eastern Tropical Pacific coral reefs. Mar Ecol 37 : 1088-1102

Alvarez-Filip L, Reyes-Bonilla H, Calderon-Aguilera LE (2006) Community structure of fishes in Cabo Pulmo reef, Gulf of California. Mar Ecol 27:253-262

Amador JA, Rivera ER, Durán-Quesada AM, Mora G, Sáenz F, Calderón B, Mora N (2016) The easternmost tropical Pacific. Part I: A climate review. Rev Biol Trop 64:S1-S22

Baldwin WJ (1963) A new chaetodont fish, Holacanthus limbaughi from the Eastern Pacific. Contrib Sci 74:1-8

Chávez-Comparán JC, Patiño-Barragán M, CalderónRiveroll G, Lezama-Cervantes B, Lara Chávez B, IbarraCasillas M, Bautista-Laureano S (2010) Lista de peces generado por censos visuales submarinos en la Isla Socorro Colima, México. Rev Cuba de Invest Pesqueras $27: 72-78$

Clua E (2016) Mission internationale sur l'atoll de Clipperton (île de La Passion-France) et les îles Revillagigedo (Mexique) du 28 janvier au 11 février 2016. Rapport de mission. CRIOBE USR3278 CNRS-EPHEUPVD. RA231

Clua E, Bessudo S, Labrecque M, Hoyos-Padilla M (2016) First record of giant trevally (Caranx ignobilis) around the Clipperton Atoll-La Passion Island (North-Eastern Tropical Pacific). Cybium 40:259-260

Craig MT, Pyle R, Rocha LA (2010) Holacanthus limbaughi. The IUCN Red List of Threatened Species 2010:e. T165836A6144988. http://dx.doi.org/10.2305/IUCN.UK. 2010-4.RLTS.T165836A6144988.en (accessed 5 September 2016)

Crane NL, Tariel J, Caselle JE, Friedlander AM and others (2018) Clipperton Atoll as a model to study small marine populations: endemism and the genomic consequences of small population size. PLOS ONE 13:e0198901

Debelius H, Tanaka H, Kuiter RH (2003) Angelfishes: a comprehensive guide to Pomacanthidae. TMC Publishers, Chorleywood

ECS (Environmental Crime Section) (2011) Monthly bulletin, September 2011, p 9. https://www.justice.gov/sites/ default/files/enrd/legacy/2015/04/13/sept_2011_508.pdf (accessed 30 October 2017)

ECS (Environmental Crime Section) (2012) Monthly bulletin, January 2012, p 17. https://www.justice.gov/sites/ default/files/enrd/legacy/2015/04/13/jan_2012_508.pdf (accessed 30 October 2017)

*Fourrière $M$, Reyes-Bonilla $H$, Rodríguez-Zaragoza FA, Crane N (2014) Fishes of Clipperton Atoll, Eastern 
Pacific: checklist, endemism and analysis of completeness of the inventory. Pac Sci 68:375-395

Friedlander AM (2001) Essential fish habitat and the effective design of marine reserves: applications for marine ornamental fishes. Aquar Sci Conserv 3:135-150

Glynn PW, Veron JEN, Wellington GM (1996) Clipperton Atoll (eastern Pacific): oceanography, geomorphology, reef-building ecology and biogeography. Coral Reefs 15: 71-99

Hawkins JP, Roberts CM, Clark V (2000) The threatened status of restricted-range coral reef fish species. Anim Conserv 3:81-88

Jost C, Friedlander A, Ballesteros E, Brown E and others (2016) L'atoll de Clipperton (île de La Passion): biodiversité, menaces et recommandations pour sa conservation. Rapport au Gouvernement de la France. Août 2016. Pristine Seas, National Geographic Society, Washington, DC

Limbaugh C (1959) August-September 1958. Field Report. IGY Clipperton Island Expedition. Scripps Institution of Oceanography, La Jolla, CA

Pyle R, Myers R, Rocha LA, Robertson R (2010) Holacanthus

Editorial responsibility: Uwe Krumme,

Rostock, Germany clarionensis. The IUCN Red List of Threatened species 2010:e.T165861A6151012 (accessed 20 July 2016)

Reyes-Bonilla H (2016) Situación actual del pez endémico Holacanthus clarionensis (Ángel Clarión) y perspectivas de conservación en México. Informe final SNIBCONABIO, CONABIO proyecto no. MM003. Universidad Autónoma de Baja California Sur, Ciudad de México

Robertson DR (1996) Holacanthus limbaughi and Stegastes baldwini, endemic fishes of Clipperton Island, Tropical Eastern Pacific. Coral Reefs 15:132

Kobertson DR (2001) Population maintenance among tropical reef fishes: inferences from small-island endemics. Proc Natl Acad Sci USA 98:5667-5670

Robertson DR, Allen GR (2015) Shorefishes of the tropical eastern Pacific: an information system. Smithsonian Tropical Research Institute, Balboa

* Robertson DR, Grove JS, McCosker JE (2004) Tropical transpacific shorefishes. Pac Sci 58:507-565

Wabnitz C, Taylor M, Green E, Razak T (2003) From ocean to aquarium: the global trade in marine ornamental species. UNEP World Conservation Monitoring Centre, Cambridge

Submitted: November 27, 2017; Accepted: January 30, 2019 Proofs received from author(s): March 21, 2019 